\title{
The Industry Employability Index: Taking account of supply and demand characteristics
}

Citation for published version (APA):

de Grip, A., van Loo, J. B., \& Sanders, J. M. A. F. (2004). The Industry Employability Index: Taking account of supply and demand characteristics. International Labour Review, 143(3), 211-233. https://doi.org/10.1111/j.1564-913X.2004.tb00269.x

Document status and date:

Published: 01/01/2004

DOI:

10.1111/j.1564-913X.2004.tb00269.x

Document Version:

Publisher's PDF, also known as Version of record

\section{Please check the document version of this publication:}

- A submitted manuscript is the version of the article upon submission and before peer-review. There can be important differences between the submitted version and the official published version of record.

People interested in the research are advised to contact the author for the final version of the publication, or visit the DOI to the publisher's website.

- The final author version and the galley proof are versions of the publication after peer review.

- The final published version features the final layout of the paper including the volume, issue and page numbers.

Link to publication

\footnotetext{
General rights rights.

- You may freely distribute the URL identifying the publication in the public portal. please follow below link for the End User Agreement:

www.umlib.nl/taverne-license

Take down policy

If you believe that this document breaches copyright please contact us at:

repository@maastrichtuniversity.nl

providing details and we will investigate your claim.
}

Copyright and moral rights for the publications made accessible in the public portal are retained by the authors and/or other copyright owners and it is a condition of accessing publications that users recognise and abide by the legal requirements associated with these

- Users may download and print one copy of any publication from the public portal for the purpose of private study or research.

- You may not further distribute the material or use it for any profit-making activity or commercial gain

If the publication is distributed under the terms of Article $25 \mathrm{fa}$ of the Dutch Copyright Act, indicated by the "Taverne" license above, 


\section{The Industry Employability Index: Taking account of supply and demand characteristics}

\section{Andries de GRIP,* Jasper van LOO* and Jos SANDERS**}

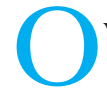

ver the past decade, the concept of employability has been the focus of considerable media attention internationally. Its growing importance is reflected not only in scientific publications, but also in government and business policies (see, for example, European Commission, 1996 and 2000; ILO, 2000). This interest is partly aroused by new ideas about career development: the model of "lifetime employment" with a single employer, it is argued, is no longer relevant for a large share of the working population (Bridges, 1994) and has been replaced by a more dynamic model based on "careers". Hyatt (1996) notes that modern careers are characterized by a high degree of flexibility and that employees are meant to become "entrepreneurs of their own career". Arthur (1994) predicted a future in which careers would no longer be bound to a single organization, arguing that individual careers would become increasingly "boundaryless". Hall (1996) empirically proved that the so-called protean career made its breakthrough in the United States in the late 1980s and early 1990s (see also Hall and Mirvis, 1996). He defines a protean career as a pattern of varied experiences in education, training, work in several organizations and changes of occupational field. An important characteristic of a protean career is that individual workers themselves, not organizations, manage it. Hirsch (1977), however, showed that the underlying notion of selfmanagement assumes a rather optimistic view on the functioning of the labour market as only the more able and ambitious people take charge of their careers instead of following an organization's policy of career development.

\footnotetext{
* Research Centre for Education and the Labour Market (ROA), Faculty of Economics and Business Administration, Maastricht University. ** TNO Work and Employment, Hoofddorp. Email: A.deGrip@ROA.unimaas.nl
} 
Besides, there has been a lot of debate about the exact meaning of "employability". This concept has indeed become somewhat fuzzy because it has come to incorporate more and more related "ingredients". Accordingly, this article first aims to provide a clear definition of the concept of employability, based on the human resource development and economic literature. This, coupled with a review of successive changes in the meaning of the concept, clearly shows that it has to encompass both individual and contextual factors because the need for flexibility and investment in further training depends largely on the particular sector of the economy in which a worker is employed.

This article's central contribution is that it conceptualizes the various factors of employability and integrates them in a synthesized index which enables comparison of workforce employability across the various sectors of the economy. To that end, account has to be taken of both supply and demand determinants of workers' employability as well as sector-specific facilitating conditions.

In the literature on employability, individuals are usually taken as the main units of analysis. This implies that employability is typically considered to be merely a "supply-side" characteristic of workers independent of the context in which they work. This article takes a different view. Employability is approached from the perspective of sectors of industry. In order to characterize the employability of the workforce in the various sectors, we develop an industry employability index that relates individual employability to the need for employability and current opportunities to effectuate employability in the particular sector of industry in which the workers are employed. The Industry Employability Index (IEI) developed in this article can be seen as embodying a stylized-facts approach that synthesizes the relevant supply- and demandside determinants of workers' employability together with the facilitating conditions discussed in the literature.

From a policy point of view, the IEI could stimulate discussion between the social partners on human resources in particular firms or sectors of industry and inform government on groups of workers whose employability is at risk (see ILO, 2000). Like the well-known indexes measuring stock market performance, competitiveness and innovation (Porter and Stern, 1999), financial assets or real estate prices, an employability index could be used as a benchmark of a sector's "employability value". Such a benchmark would also make clear that employability is not only an asset of individual workers but also an advantage for the firms in which they are employed. Moreover, an employability index makes the labour market more transparent for employees who want to gain a better understanding of career development opportunities and employability risks in the various sectors of industry. 
The IEI developed in this article gives a cross-sectoral picture of workforce employability. In addition, separate indexes are developed for young workers, older workers, low-skilled workers and female workers, making it possible to examine sector by sector the specific employability of those workers who are often targeted by employment policies.

The first section of the article examines the concept of employability and reviews the changes that have occurred in its meaning over the years. The second section explains how employability can be measured at the sectoral level and outlines the successive stages in the development of the IEI. The third section is devoted to further elaboration on those stages and their operationalization. Using various data sources, the IEI methodology is then applied to the economy of the Netherlands in the fourth section. A concluding section summarizes the main insights gained from the research.

\section{Employability: Historical overview and meaning of the concept}

The concept of employability is not new. The term itself first appeared at the beginning of the twentieth century in the United Kingdom. As Mansfield (2001) points out, it was Beveridge (1909) who introduced the idea of employability in 1909. The concept was then further developed in the United States, where it was initially defined in terms of the availability of able-bodied workers. The point of this conception was to distinguish between people eligible for relief (unemployable) - e.g. the elderly - and people looking for work (employable). Gazier (1999) calls this concept of employability "dichotomic employability".

Another early publication on employability dates back to the mid1950s (Feintuch, 1955). By that time, concern with employability centred on the labour market position of the underprivileged, such as the physically, mentally or socially disabled. Here, the underlying concept is also referred to as "socio-medical employability" (Gazier, 1999). The main reason why the underprivileged received so much attention from policy-makers was the shortage of skilled workers in the post-war period, which caused firms to focus their recruitment efforts on them.

In the 1950s and 1960s employability was understood in terms of individual potential to become employed. It was described primarily as the "distance" separating individuals - at first the disadvantaged and, later, others too - from regular employment. Gazier (1999) calls this version of employability the "manpower policy" version. Collecting information on the potential of individuals and stimulating it was supposed to lead to full employment in (American) society, which was the first priority of governments (Feintuch, 1955; Forsyth and Nininger, 
1966). Promoting employability served a purely macroeconomic purpose. The employability of a worker was determined mainly by looking at his or her labour market history. Policy-makers attempted to improve people's employability by influencing their attitude towards employment in general and improving their self-perception - i.e. the image people have of themselves - in order to assist the labour market re-entry of those who had lost their self-confidence. Measuring employability by relying on attitudes and using the resulting information to improve labour market allocation was common practice until the beginning of the 1970s (Forsyth and Nininger, 1966; Soloff and Bolton, 1969).

From 1970 onwards, attention shifted away from "attitudes" and became increasingly focused on individual - mainly occupational knowledge and skill endowments and their labour market value. This conception extended not only to basic occupational skills, but also, crucially, to knowledge about one's own possibilities (Tseng, 1972), knowledge about one's own position on the labour market (Mangum, 1976) and knowledge about the employment situation in general (Orr, 1973). Towards the end of the 1970s, partly as a result of the economic recessions that plagued the industrialized countries, firms as well as researchers realized that occupational skills per se were not sufficient to ensure sustained attractiveness on the labour market (Weisenstein, 1979). Hoyt (1978) acknowledged the importance of "transferable" skills, which retain their value across many different work situations and make employees less vulnerable in a weak labour market. Transferable skills include social and relational skills that are not only important in obtaining a job, but also in keeping it and, eventually, in moving on to the next job. During the 1970s, employability also became important to individuals because recession made it harder to find and keep employment. Employability generally came to be viewed in terms of future labour market outcomes (wages) for individuals (or specific groups) based on their human capital. This concept of employability has been described as the "labour market performance" version (Gazier, 1999).

Since 1980, employability has become a meta-characteristic of workers required by employers to cope with rapid changes in products, services and processes. Because of fluctuations in their employment needs, employers gradually started hiring more workers on a temporary basis and on flexible part-time contracts so that they could easily adjust working time to variations in demand. Such arrangements caused the labour market to split into two segments: a primary segment, consisting of personnel with permanent jobs, and a secondary segment, consisting of people with temporary contracts and flexible part-timers. Investment in employability became confined to those working in the primary segment or at the core of firms' internal labour markets (Atkinson, 1984; Handy, 1989; Smith, 1976). 
In the 1980s, the concept of employability as a "meta-characteristic" combining attitudes, knowledge and skills was considered to be an important determinant of employees' labour market performance (Pearson, 1988). With economic activity increasingly dependent on flexibility, employability gradually came to exert an important influence over every stage of workers' careers (Bhearmann and Spill, 1988; Charner, 1988). These labour market developments gave rise to the perception that all workers had to expect discontinuities in their careers. In the circumstances, employability was equated with the marketability of an individual's cumulative skills. Gazier (1999) calls this the "initiative" version of employability. According to this view, the "employable individual" is a permanent entrepreneur of his or her own "boundaryless career" (Arthur, 1994).

Around 1990, the concept of employability was further broadened by the incorporation of other dimensions such as the labour market situation, knowledge of the labour market and company policies (Bloch and Bates, 1995; Hyatt, 1996; Outin, 1990; Sterns and Dorsett, 1994). Outin (1990), for instance, sees employability as a construct of four elements that influence one's chances to become and/or remain active on the labour market, namely: individual qualities (relational, motivational), occupation-specific skills, labour market situation, and government and employer training policies. Employability thus becomes a shared responsibility of government, employers/companies and the individual employee. Gazier (1999) calls this the "interactive" version of employability, in which all labour market actors and institutions are mobilized.

The 1990s, however, brought widening differences between opinions on what employability actually means, how it should be measured and how it affects people. For some authors, the most important considerations are labour market potential and occupational skills (Gazier, 1990). Others focus mainly on the possible applications of employability in organizations (Levy et al., 1992); or on the labour market situation and the responsibility of government and firms (Outin, 1990); or on the capacity to "steer" one's own career (Bloch and Bates, 1995); or yet on how to deal with changes inside the company (Hyatt, 1996). Although definitions of employability have become highly diverse - ultimately making the concept itself rather fuzzy - employability had, by the end of the twentieth century, become one of the main topics in the debate on human resource development in a globalizing economy and one of the "pillars" of the European Employment Strategy (European Commission, 2000; ILO, 2000).

As Gazier (1999) argues, in the interactive version of employability it is important to find the right balance between individual and collective responsibility and scope. In order to structure the interactive concept of employability, Thijssen (1998) suggests a "stratification" of 
existing definitions of employability, distinguishing between three levels of definition: a core definition, a broader definition, and an allembracing definition. The core definition covers individual potential for being successful in a variety of jobs in a given labour market situation. Here, employability is concerned only with a worker's capabilities; wishes, aspirations or contextual conditions are not relevant. The broader definition of employability incorporates the willingness as well as the capacity to be successful in a variety of jobs. It also includes the ability to learn. In other words, the broader definition of employability encompasses all the individual characteristics that determine a worker's future position on a given labour market. In the all-embracing definition, contextual factors and so-called effectuation conditions are added. "Effectuation conditions" are context-specific factors that help, or make it harder, to effectuate one's employability (e.g. employer provision of training). In the all-embracing definition, employability encompasses all the individual and contextual conditions that determine a worker's future position on the labour market.

A thorough analysis of the literature reveals that three aspects are central to the modern concept of employability: employability is about employees who are willing and able to be as pro-active as possible - considering organizational and institutional constraints - to remain attractive for the labour market. We therefore define the employability of workers as follows:

Employability refers to the capacity and willingness of workers to remain attractive for the labour market (supply factors), by reacting to and anticipating changes in tasks and work environment (demand factors), facilitated by the human resource development instruments available to them (institutions).

From an economic point of view, it is worth noting that this definition refers to both labour supply and demand characteristics. Moreover, the definition implies that the employability of workers is the shared responsibility of individual workers and of the firms that employ them, while also highlighting the importance of a firm's HRD and supportive sectoral and government policies in maintaining and enhancing workers' employability (e.g. training funds, labour laws, etc.).

\section{Employability and sectors of industry}

Most of the modern literature concerned with employability approaches this concept from the employee's point of view. Yet the effects of employability are not confined to individuals. Enhancing workers' employability increases their value not only from the perspective of the firms they work for, but also on the external labour market, particularly when the process involves investments in transferable skills. 
Employers are therefore faced with a dilemma. When they enhance their workers' employability, they are in effect boosting their own firms' potential productivity and profits by investing in extra flexibility, which allows them to react and adjust faster to changes (Atkinson, 1984). But investments in workers' transferable skills imply that other "poaching" firms will reap part of the benefits (see, for example, Acemoglu and Pischke, 1999; Stevens, 1994).

Gaspersz and Ott (1996) counter this argument with what they call the "employability paradox": an employer who invests in her/his employees' employability tends to attach workers to her/his firm by increasing their mobility potential. In addition, employers who invest substantially in their human capital signal an "excellent employer" image, which makes it easier for them to attract high-potential personnel.

In this article, employability is considered from the perspective of sectors of industry. This approach contrasts with that taken in the existing literature, which makes no distinction between the labour market segments in which workers are employed and, therefore, takes no account of inter-sectoral variation in the need for employability.

This section further develops the conceptual model underlying the proposed measure of employability at the industry level. This will enable us to assess the employability of the workforce of the various sectors of industry by using a single index. The operationalization of the IEI may be divided into the following four stages:

1. Determining current workforce employability by sector of industry;

2. Determining the influence of relevant societal developments on the need for employability by sector of industry;

3. Determining effectuation conditions, i.e. the conditions under which workers can effectuate their employability within various sectors of industry;

4. Combining stages 1 through 3 into the IEI.

\section{Current workforce employability}

The first stage concerns the measurement of the employability of the current workforce by sector of industry. Two dimensions of individual employability will be used. The first - willingness - measures peoples' desire to engage in activities that keep them attractive on the labour market. The second - capacity - is concerned with the power to develop one's position on the labour market. Based on the employability literature, current workforce employability may be measured by six indicators; three of them measure willingness, while the other three are concerned with capacity (see Bolweg and Maenhout, 1995). 


\section{Mobility}

The willingness to be mobile across jobs is about changing jobs as well as changing locations, both internally and externally. Various authors consider this attribute of workers a key factor in their employability since such changes allow workers to gain more knowledge and experience (Bridges, 1994; Hall, 1976 and 1996). It also prevents "concentration of experience" (Thijssen, 1997). Concentration of experience refers to the process whereby competences become more and more job-specific due to long tenure in the same job in the same firm. Concentration of experience can be damaging for workers because it reduces their value on the labour market and thereby also restricts their opportunities for switching to another job in the event of job loss.

The capacity to be mobile across jobs is the extent to which employees are actually able to change jobs or work locations. Though such mobility is predicated on willingness, this willingness is less valuable when people lack the capacity to become mobile. The capacity to be mobile across jobs is therefore the second indicator of the employability of a sector's workforce. An employee's capacity to be mobile across jobs is largely determined by experience gained in previous jobs. But job-specific skills can imply serious constraints because a highly specialized skill base will only be valuable in a limited number of places (see, for example, Booth and Snower, 1996; Hashimoto, 1981).

\section{Training}

The willingness to participate in training refers to workers' willingness to invest time, money and energy in the development of their own human capital. Early human capital theorists have pointed out that employees' willingness to invest in their own human capital depends on the expected return on their investment (Becker, 1962; Holtmann, 1972). This return consists not solely of a direct increase in earnings, but also of an improved labour market position and an improvement of one's earnings potential (Rosen, 1975). This implies that workers who are not willing to invest in their human capital run a double risk. Firstly, they do not develop themselves, which worsens the consequences of skills obsolescence (see also de Grip and van Loo, 2002) and makes them less attractive for the labour market; and secondly, they give a negative signal to (future) employers which may reduce their chances when employers "screen" jobseekers (Thurow, 1975). Willingness to participate in training is therefore an important indicator of employability.

At least as important as willingness is the capacity to participate in training. This can be determined by assessing three types of worker knowledge, namely, basic knowledge (i.e. knowledge acquired during initial education); meta-cognitive knowledge (i.e. knowledge and opin- 
ions about learning); and knowledge and opinions about one's own learning capacities (Bolhuis, 1995).

The first type, basic knowledge, is crucial in that it determines workers' subsequent ability to learn. The more extensive this basic knowledge, the easier it is to learn new skills (see also Heckman, 1999). In this framework, initial education can be regarded as a "positional good", which implies that higher initial education improves workers' labour market position and employability (Arrow, 1973). The second type, meta-cognitive knowledge, facilitates the process of learning. For example, knowing where to find specific information is part of this type of knowledge; and especially in very technology-intensive sectors of industry, it is highly valued. The third type of knowledge has a more psychological character. Knowledge and opinions about one's own learning capacities may indeed influence the decision to participate in training.

\section{Functional flexibility}

Functional flexibility can be either quantitative or qualitative (Bolweg and Van Beckhoven, 1995). Qualitative functional flexibility refers to a worker's willingness to perform tasks or duties that are outside her/his current job description, while quantitative functional flexibility refers to flexibility concerning hours of work (e.g. changing shifts, working overtime, etc.). Willingness to be functionally flexible is a measure of someone's flexibility in a job and is therefore a useful indicator of individual employability.

When someone is willing to be functionally flexible but lacks the capacity to act accordingly, their willingness does not add much to their employability. The capacity to be functionally flexible results largely from actual functional flexibility in the past, and the consequent accumulation of a wide range of valuable experience. Indeed, experience plays a central role here, just as it does in determining a worker's capacity to be mobile across jobs. The essential difference between the two concepts, however, is that the capacity to be mobile across jobs is about changing jobs, while the capacity to be functionally flexible is about performing tasks outside one's job description.

\section{The need for employability: Societal developments}

As mentioned above, the employability of the workers in a given sector of industry also depends on the extent to which they need employability in order to cope with developments in their particular sector. The need for employability, in turn, therefore depends on the sectoral intensity of various developments and the characteristics of the markets in which the sector's firms sell their products or services. Four main types of development can be distinguished (Riddell and Sweetman, 2000): 
- Technological developments;

- Organizational developments;

- Economic developments (mainly related to competition);

- Demographic developments.

Ongoing technological developments can cause obsolescence of job-specific skills. In other words, skills and experience acquired in the past gradually become insufficient for adequate job performance (see, for example, Blechinger and Pfeiffer, 2000; Neuman and Weiss, 1995). And when the skill requirements of particular jobs are upgraded, a gap opens up between the human capital workers possess and the required human capital (Bartel and Sicherman, 1995; Borghans and de Grip, 2000). Employability plays an important part in bridging that gap.

Technological developments can also cause jobs to disappear altogether. In the banking sector, for example, information technology has caused the disappearance of traditional teller jobs. When jobs disappear, workers' employability becomes crucial to their continued labour market participation. In this case, however, employers also benefit from their workers' employability since they do not have to bear the cost of placement procedures for those who have to be redeployed.

Technological developments are often concomitant with organizational changes (see Bresnahan, Brynjolfsson and Hitt, 2001; Caroli and Van Reenen, 2001). Organizational developments are very demanding on workers in that they must continuously adapt to new circumstances. Modern organizations have an inherent need for flexibility. The more bureaucratic organizations of the past are making way for less rigid ones, whose employees often work in project teams with a considerable measure of control over their own actions (but see Lindbeck and Snower, 2000). Organizational developments demand a high degree of flexibility, which can be accomplished by means of employability. When workers are used to changes in the content of their job because they are regularly involved in task- and job-rotation programmes or training, both the organization and its employees are in a better position to adapt to rapid changes (Maroy and Fusulier, 1995; Riddell and Sweetman, 2000).

A third important development faced by several sectors of industry is the increase in international competition. The firms in these sectors need to be able to adapt more rapidly to changes in the international environment. This, in turn, increases their need for a flexible workforce. Moreover, labour-intensive production processes have moved to low-wage countries around the globe (Wood, 1994), while knowledge-intensive production processes like $\mathrm{R} \& \mathrm{D}$ and innovation seem to be concentrated in western Europe, Japan and the United States. As a result, most organizations in the industrialized countries have started to focus their competitive strategies on knowledge and 
innovative capacity (Porter, 1990). Since well-trained workers are generally better innovators, good training programmes should be a key priority for all firms whose competitiveness is closely related to the quality of their products or services (Bartel and Lichtenberg, 1987; Corvers, 1997). Increasing international competition thus requires both flexibility and training efforts on the part of employees.

Finally, demographic developments also contribute powerfully to the need for an employable workforce. In many industrialized economies, the proportion of workers older than 55 is set to increase sharply in the immediate future, as the proportion of those below 40 years of age is expected to decrease both in absolute and in relative terms. Due to the ageing of the workforce, established channels of labour market exit (e.g. early retirement, etc.) will become less common, simply because the associated costs will increase to unsustainable levels. Indeed, in many industrialized economies, projections of an increasingly short supply of younger workers imply that employers will come under growing pressure to retain their personnel longer.

\section{Conditions of effectuation}

The previous two sub-sections have reviewed various factors relevant to actual employability and to the need for employability. But when current employability is inadequate, it is profitable for both employees and firms to invest in personnel employability policies. In this third stage, we will identify the possibilities that currently exist within sectors of industry to effectuate or expand workers' employability. Following Thijssen (1998), these possibilities are labelled "conditions of effectuation".

Thijssen (1998) distinguishes between two types of conditions of effectuation. Contextual conditions of effectuation refer, inter alia, to the general situation on the labour market, the possibilities for career counselling, and the provision of training courses. Personal conditions of effectuation refer to the willingness and preferences of individual employees. Since this latter type of conditions of effectuation has already been dealt with above in terms of individual employability, the conditions of effectuation considered here are strictly contextual.

\section{The Industry Employability Index}

The final stage of the model consists in constructing the IEI using the various indicators discussed above. If a sector of industry has, say, a high level of current employability, a moderate need for employability and favourable conditions of effectuation, its IEI score will be relatively high. When a sector scores badly on one or more of these indicators, its IEI score will automatically be lower. The IEI may be calculated for the 
entire workforce, but also for specific groups of workers - typically "target groups" considered to deserve special attention in terms of labour market policies, e.g. young workers (16-29 years of age), older workers (50-64 years of age), low-educated workers, and women.

\section{Data and operationalization}

In this section, the proposed methodology for calculating the IEI is applied to the Dutch economy. Since the required data are not available from a single source, the empirical part of this article uses various Dutch data sources, namely: the labour supply and labour demand surveys of the Organisation for Strategic Labour Market Research (OSA) and the labour force survey of Statistics Netherlands (CBS). These various data sources refer more or less to the same point in time, in the mid-1990s. The OSA supply survey data refer to 1996; the OSA demand survey data, to 1997; and the CBS data, to the bi-annual average for 1996-1997 (CBS/CPB, 1997). For the purposes of comparability, all data were indexed by converting them into standard, evenly distributed variables and re-scaling them such that the average score was 100 . This implies that the resulting IEI is not an absolute measure, but a relative measure meant to compare the various sectors of industry according to their employability. This section describes and explains our choice of indicators.

\section{Current individual employability}

The willingness to be mobile can best be measured using data on workers' actual search behaviour. When employees apply for new jobs on a regular basis they express their willingness to be mobile across jobs. However, not all search behaviour can be considered relevant here. Search behaviour can also be caused by external factors (e.g. anticipated job loss in the near future). Such "forced" search behaviour should therefore not be seen as employability-enhancing. For this reason, the focus here will be on job search by workers acting on their own initiative. When employees search for another job on their own initiative, they signal a willingness to be mobile and add to their employability. The willingness to be mobile across jobs is measured using data on workers' current search behaviour and on their search behaviour in the immediate past.

In order to measure a worker's capacity to be mobile across jobs, we looked at the current-job tenure of individual workers and divided this by the duration of individual workers' labour force participation. This ratio is then multiplied by the worker's age, because older workers run a greater risk of "concentration of experience" (Rosen, 1975), which reduces their capacity to be mobile. 
The willingness to participate in training is measured using data on actual participation in training. This indicator does not take account of whether or not an employee has successfully completed a training course, as this is not relevant to her/his willingness to participate in training.

The capacity to participate in training is measured by the total duration of initial education and previous (firm-based) training. This reflects Heckman's notion that: "Learning begets learning. Skills acquired early on make later learning easier. More able people find learning easier" (1999, p. 6). In this sense, initial training provides the foundation of a worker's employability (ILO, 2000). Here, account is taken only of initial education and additional training courses that were successfully completed. Part-time training courses were converted to full-time equivalents. The resulting number of years of education/training determines a worker's training experience and, therefore, her/his capacity to participate in further training.

Qualitative functional flexibility endows workers with a wide range of different experiences, which improves their employability. However, the willingness to be quantitatively flexible can also indicate a weak position in the (secondary) labour market, as workers employed in "atypical jobs" - e.g. temporary and involuntary part-time jobs - are probably more "willing" to be flexible in their working hours than workers who have more stable, regular contracts (de Grip, Hoevenberg and Willems, 1997). The measurement of willingness to be functionally flexible is therefore confined to the qualitative dimension of functional flexibility.

Finally, the capacity to be functionally flexible is measured by past experience of qualitative functional flexibility. This is calculated by determining the frequency with which a worker performed tasks that were not part of her/his job in the past.

\section{The need for employability}

Highly innovative sectors of industry are in great need of employability. Production processes in these sectors are characterized by technological and organizational changes. Since technological developments in many sectors of industry are closely connected with improvements or changes in information and communication technology, the percentage of the workforce in a sector of industry that uses a computer regularly at work has been used as an indicator of technological developments.

A combination of two indicators is used to measure organizational developments. The first indicator is the percentage of employees to have experienced reorganizations. The second is the percentage of people who work for a firm that has undergone a change of position within 
the broader corporate configuration (parent company, franchisee, etc.). ${ }^{1}$

Sectors that are open to international competition, are expected to have a relatively high need for employability. The degree of international competition in a given sector of industry is measured through the export share of the industry's production, as a proxy for the degree of "openness" of a sector.

Finally, sectors of industry with an ageing workforce are also in great need of employability, as their workforce may have obsolete human capital (Neuman and Weiss, 1995; Rosen, 1975). Demographic developments affecting the workforce of a given sector have been measured by dividing the percentage of older workers (55+) by the percentage of young workers (16-29 years). This indicator shows the severity of ageing in the various sectors of industry and the effect of the declining share of younger workers in the working population.

\section{Conditions of effectuation}

Contextual conditions of effectuation are determined using two indicators. The first is training provision in the different sectors of industry, which is measured by the supply of training facilities provided by the firms in each sector. The second indicator is the general labour market situation, since a strong labour market will offer workers more opportunities for career advancement and alternative employment than a labour market with shrinking employment. The general labour market situation in a given sector is therefore indicated by expected employment growth in the next five years (ROA, 1997).

\section{Empirical results}

This section presents the empirical results obtained when the foregoing methodology is applied to the Dutch economy. Table 1 presents all of the indicators discussed above.

The current individual employability of the workforce by sector of industry is presented in the first seven columns, starting with the six separate employability indicators. In the seventh column, all of these indicators are combined into a single unweighted index (MTF score). The data show that the sectors of industry do not differ widely in terms of current workforce employability. Financial services and hotels/restaurants, repair and business services are the sectors with the highest

1 Another possible indicator would be the percentage of workers employed in a "high performance workplace" as indicated by, say, the number of workers involved in team work or employed in decentralized and delayered "holistic organizations" (see, for example, Caroli and Van Reenen, 2001; Lindbeck and Snower, 2000). 


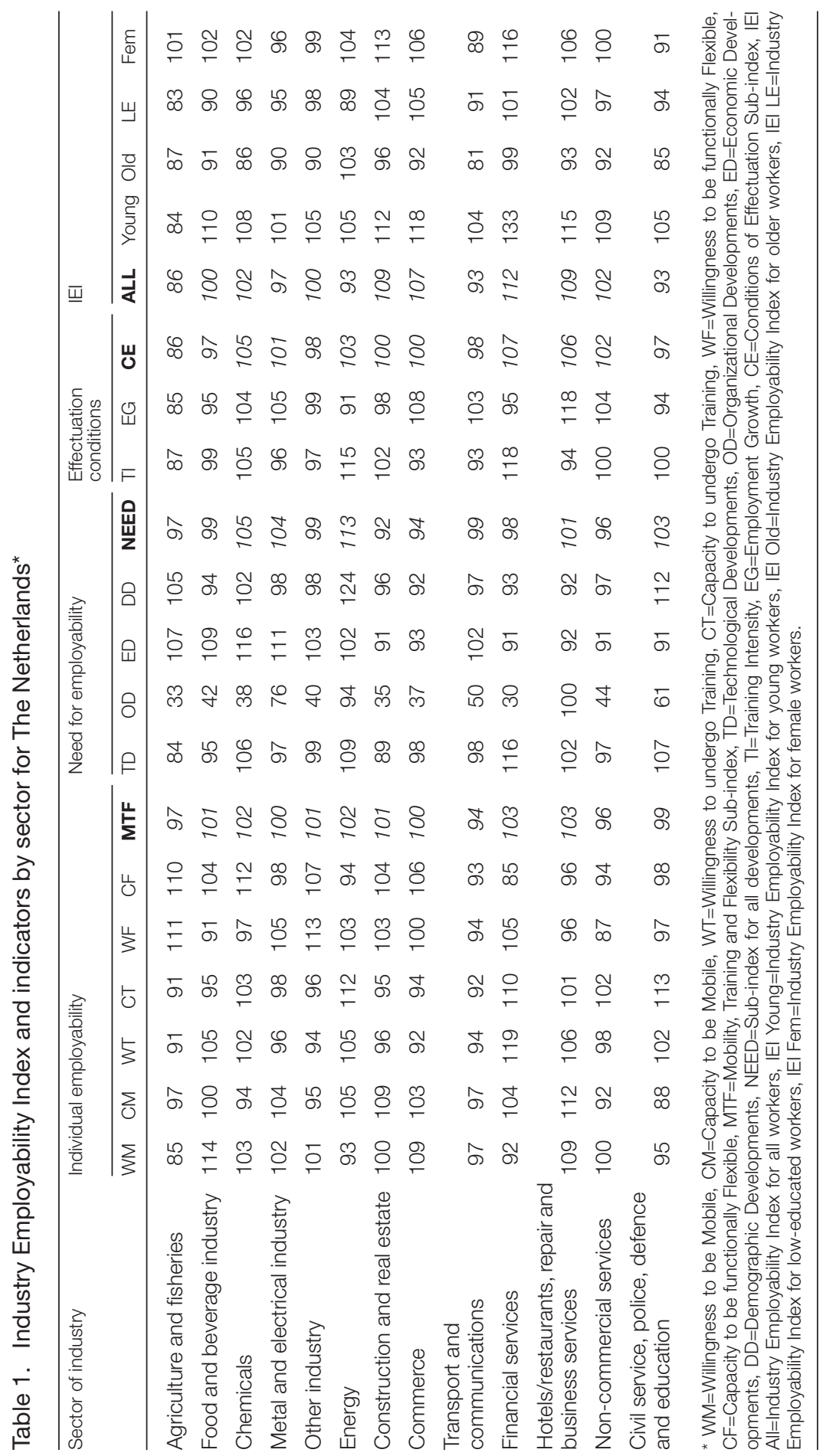


overall scores on individual employability. The transport and communications sector scores below 100 on every single employability indicator, making its employees the least "employable" on average. Noncommercial services are also in a relatively bad state in terms of current workforce employability.

Columns 8 through 12 present the four indicators of the need for employability. Technological developments (TD) clearly play an important role in the sectors of financial services, chemicals, energy and civil service, police, defence and education. Organizational developments (OD) are most prominent in hotels/restaurants, repair and business services, though the metal and electrical industry sector is also characterized by significant organizational developments. Financial services and agriculture and fisheries are organizationally the most stable sectors. International competition (ED) plays an important role in the chemicals sector, making it the most open of all. Workforce ageing (DD) is most prominent in the energy and civil service, police, defence and education sectors.

Combining the above four indicators, the overall need for employability is shown in the NEED column. The need for employability is greatest in the energy sector, due to the relatively strong effect of all individual developments. The chemicals sector, which scores over 100 on three of the four indicators, comes second on the NEED index. The sectors of metal and electrical industry and civil service, police, defence and education rank third and fourth, respectively. In these sectors, organizational and demographic developments (OD and DD) are of key importance.

The conditions of effectuation of workers' employability are presented in columns 13-15. The share of employees involved in job training - i.e. training intensity (TI) - is highest in the financial services and energy sectors. At the other end of the spectrum, employees in agriculture and fisheries are the least involved in training. As shown by the indicator of expected employment growth in the various sectors (EG), the employment outlook is very favourable in the sectors of hotels/restaurants, repair and business services and commerce (3.6 and 2.2 per cent growth, respectively). The employment growth forecasts are far less favourable in the agriculture and fisheries and energy sectors. The $\mathrm{CE}$ column, which combines both of these contextual conditions of effectuation, reveals that the three sectors with the most favourable conditions of effectuation are financial services, hotels/restaurants, repair and business services and chemicals. By contrast, the agriculture and fisheries, food and beverage and civil service, police, defence and education sectors score relatively low on the conditions of effectuation index. The agriculture and fisheries sector, in particular, faces poor conditions of effectuation because of shrinking employment coupled with low training intensity. 
The next column in table 1 presents the IEI for all workers (All). The financial services sector has the best score, mainly on account of its high MTF scores and favourable conditions of effectuation (CE). The construction and real estate sector comes second: despite its relatively modest MTF score (ranking fifth), it has the lowest need for employability. This combination implies that available employability (MTF score) at least partly offsets the demand for employable workers (NEED score). Besides, this sector's conditions of effectuation are favourable too. The agriculture and fisheries sector has the worst score on the IEI. The individual employability of workers in this sector (MTF score) is fairly low; and although its need for employability is not that high, its relatively unfavourable conditions of effectuation (CE score) give the sector the last position on the IEI index.

\section{The IEl for specific groups of workers}

The last four columns in table 1 present the IEI for young workers (Young), older workers (Old), low-educated workers (LE) and women (Fem). For young workers (16-29 years old), the most favourable conditions are found in the financial services sector. The commerce and hotels/restaurants, repair and business services sectors come second and third, respectively. As expressed in their MTF scores (not shown in table 1) the current employability of young workers in these sectors lags somewhat behind. The agriculture and fisheries sector has the least favourable employability situation, due to its strong need for employability combined with a low MTF score and relatively unfavourable conditions of effectuation. The transport and communications and the metal and electrical industry sectors show relatively unfavourable employability conditions for younger workers as well, mainly because of these sectors' low MTF scores.

Comparing the scores of older workers to those of young workers reveals that the IEI values for workers aged over 50 are lower in virtually every sector of industry. For older employees, the conditions are most favourable in the energy sector, due to the combination of its relatively high level of current workforce employability, its moderate need for employability, and its relatively favourable conditions of effectuation. The financial services and construction and real estate sectors also show a relatively good situation for older workers. In the latter sector, this can be attributed to the relatively low need for employability. Older workers in the sectors of transport and communications, civil service, police, defence and education, and chemicals face the worst employability prospects. In the first of these three sectors, the employability situation is the worst of all because of the unfavourable current individual employability of older workers. In the other two sectors, the need for employability is fairly high. Another reason for the bad score 
of the civil service, police, defence and education sector lies in its limited conditions of effectuation. It is worth noting that the IEI score of older workers in the chemicals industry is very low (ranking tenth) in comparison to that of the general workforce (ranking fifth).

The IEI for low-educated workers (LE) refers to workers with an educational background equivalent to - or less than - basic vocational or general education. As was the case with the general workforce, the sectors of commerce, construction and real estate, financial services and hotels/restaurants, repair and business services are those that have the best scores for low-educated workers, while the agriculture and fisheries sector ranks last. Of these sectors, commerce does best because of this sector's high level of current workforce employability. The construction and real estate and commerce sectors are the only ones where current employability is higher than the need for employability. Since both sectors are characterized by relatively good conditions of effectuation, they end up with favourable IEI scores. In the agriculture and fisheries sector, the low individual employability of the low-educated is combined with a high need for employability and relatively unfavourable conditions of effectuation. As a result, this sector has the worst IEI score for low-educated workers.

The differences between female workers and the overall working population are small. In a number of sectors, the employability situation is better for female workers than it is for the general workforce. This may be largely due to the fact that the proportion of women in the group of older workers is relatively small because of the very low labour force participation of women above 50. As was the case with the general working population, the employability of female workers is highest in the sectors of financial services and construction and real estate and lowest in the transport and communications sector. In this last sector, the individual employability of female workers is even worse than that of the total working population.

\section{Concluding remarks}

Although employability seems to be a key element in recent policy debates, this concept still lacks both a sound theoretical base and quantitative (international) research. One of the main problems in the current debate on employability is the definition of the concept itself. Since employability has been studied from various perspectives, many different definitions - reflecting different levels of aggregation - have been proposed.

The first part of this article reviewed the changes in the meaning of employability from the beginning of the twentieth century onwards. The second part discussed how to determine the level of workforce employability in a given sector of industry. The approach proposed 
here contrasts with that taken in the general literature on employability, which usually discusses this subject from an employee's point of view only. However, it still fits the "interactive" version of employability that aims to strike a balance between individual and collective responsibility and scope (Gazier, 1999).

Among economies where knowledge plays a key role, human resources determine to a large extent the international competitiveness of firms, sectors of industry and countries (Porter, 1990). Adequate information on workforce employability in the various sectors of a country's economy is therefore highly important. Employees as well as employers/firms have a shared interest in knowing about the current state of employability, while governments could use the information to sharpen the focus of their pro-active labour market policies.

The Industry Employability Index (IEI) developed in this article can be seen as embodying a stylized-facts approach that synthesizes the relevant supply- and demand-side determinants of workers' employability together with the facilitating conditions discussed in the literature. The first step in constructing the proposed IEI was to develop a conceptual framework that gives a quantitative indication of the relative performances of the various sectors of industry in terms of their workforce employability. This framework takes account not only of current workforce employability, but also of the need for employability in the various sectors of industry and conditions of effectuation, which refer to the degree to which employees can "effectuate" or enhance their employability. Taken together, these three elements determine the relative positions of sectors of industry on the IEI.

In the last part of the article, the model was applied to 13 sectors of the Dutch economy. The financial services sector scores highest on the IEI. Other sectors with favourable IEI-scores are construction and real estate and hotels/restaurants, repair and business services. The agriculture and fisheries sector scores worst in terms of overall employability. Indeed, the separate indicators for this sector show that its workers' participation in training and willingness to be mobile are very low, while the sector also suffers from shrinking employment, severe international competition and workforce ageing.

Policies to increase the employability of the workers in agriculture and fisheries in the Netherlands should focus on the major determinants of this sector's poor performance on workforce employability. According to the relevant indicators, this means that employability policies should focus on the promotion of training that motivates and enables workers in this sector to switch to other fields of employment. Moreover, the social partners and the Government could consider facilitating early retirement among the sector's ageing workforce as an alternative to paying for workers to be retrained. In a similar way, the indicators used to compile the IEI for the other sectors of industry point 
to human resource strategies that can improve the employability of the workforce in these sectors.

The IEI scores for specific groups of workers show that the employability situation for older workers is generally a lot worse than it is for their younger colleagues. Also, somewhat predictably, low-educated workers are less "employable" than intermediate or highlyeducated individuals. Differences between male and female workers are, however, rather small.

To obtain a more detailed picture of workers' employability, the collection of firm-specific data would be extremely helpful. Such data on individual organizations would make it possible to construct a firmlevel employability index. This, in turn, would make the labour market more transparent for workers seeking information on career development opportunities and employability risks in the firms where they intend to apply for a job. Furthermore, organizations could gain valuable insights into their own relative employability situation by comparing their organization-specific employability scores to the IEI scores for their sector of industry. Such a "benchmark" would also, once again, make it clear that employability depends not only on workers, but also on the organization and sector of industry in which they are employed. The scores of individual firms could also be related to the "Investors in People" standard, which also strives to benchmark workers' employability prospects (see Down and Smith, 1998).

Another very interesting research opportunity would be to use the framework developed in this article for international comparisons of sector-specific employability across different countries. Many countries have data sources similar to those used here to construct the IEI for the Netherlands. It would indeed be worth the effort to construct the index for more countries: the IEI offers a framework that makes the labour market more transparent not only for the benefit of individual employees, but also for firms, the social partners and governments that feel responsible for designing adequate $\mathrm{HRD}$ policies to maintain and enhance the employability of the working population in a knowledgebased economy.

\section{References}

Acemoglu, Daron; Pischke, Jörn-Steffen. 1999. "Beyond Becker: Training in imperfect labor markets", in Economic Journal (Oxford), Vol. 109, No. 453 (Feb.), pp. 112-142.

Arrow, Kenneth J. 1973. "Higher education as a filter", in Journal of Public Economics (Lausanne), Vol. 2, No. 3 (July), pp. 193-216.

Arthur, Michael B. 1994. "The boundaryless career: A new perspective for organizational inquiry", in Journal of Organizational Behaviour (Chichester), Vol. 15, No. 4 (July), pp. 295-306.

Atkinson, John. 1984. "Manpower strategies for flexible organizations", in Personnel Management (London), Vol. 16, No. 8 (Aug.), pp. 28-31. 
Bartel, Ann P.; Lichtenberg, Frank R. 1987. "The comparative advantage of educated workers in implementing new technology", in Review of Economics and Statistics (Amsterdam), Vol. 69, No. 1 (Feb.), pp. 1-11.

-; Sicherman, Nachum. 1995. Technological change and the skill acquisition of young workers. NBER Working Paper No. 5107. Cambridge, MA, National Bureau of Economic Research.

Becker, Gary S. 1962. "Investment in human capital: A theoretical analysis", in Journal of Political Economy (Chicago, IL), Vol. 70, No. 5, pp. 9-49.

Beveridge, William Henry. 1909. Unemployment: A problem of industry. London, Longmans, Green and Co.

Bhearmann, R.; Spill, R. 1988. "A dialogue on employability skills: How can they be taught?", in Journal of Career Development (New York, NY), Vol. 15, No. 1, pp. 41-52.

Blechinger, Doris; Pfeiffer, Friedhelm. 2000. "Technological change and skill obsolescence: The case of German apprenticeship training", in Hans Heijke and Joan Muysken (eds.): Education and training in a knowledge-based economy. London, Macmillan, pp. 243-276.

Bloch, Susan; Bates, Terence. 1995. Employability: Your way to career success. London, Kogan Page.

Bolhuis, Sanneke. 1995. Leren en Veranderen bij Volwassenen: Een Nieuwe Benadering. Bussum, Coutinho.

Bolweg, J. F.; Maenhout, J. M. M. 1995. "Full-employability: Economisch noodzakelijk, sociologisch naief?", in L. Faase, M. Ott and C. J. Voss (eds.): Nieuwe Breukvlakken in het Arbeidsbestel: Balans van 10 jaar veranderingen in Nederland en België. Utrecht, De Tijdstroom, pp. 92-99.

-; Van Beckhoven, G. 1995. "Employability: Een Nieuw Doel voor de P- en O-Functie?”, in Gids Voor Personeelsmanagement (Deventer), Vol. 70, No. 12, pp. 55-57.

Booth, Alison L.; Snower, Dennis J. (eds.). 1996. Acquiring skills: Market failures, their symptoms and policy responses. Cambridge, Cambridge University Press.

Borghans, Lex; de Grip, Andries. 2000. "Skills and low pay: Upgrading or overeducation?", in Mary Gregory, Wiemer Salverda and Stephen Bazen (eds.): Labour market inequalities: Problems and policies of low-wage employment in international perspective. Oxford, Oxford University Press, pp. 198-223.

Bresnahan, Timothy F.; Brynjolfsson, Erik; Hitt, Lorin M. 2001. "Information technology, workplace organization and the demand for skilled labor: Firm level evidence", in Quarterly Journal of Economics (Cambridge, MA), Vol. 117, No. 1 (Feb.), pp. 339-376.

Bridges, William. 1994. Jobshift: How to prosper in a workplace without jobs. Reading, MA, Addison-Wesley.

Caroli, Eve; Van Reenen, John. 2001. "Skill-biased organizational change? Evidence from a panel of British and French establishments", in Quarterly Journal of Economics (Cambridge, MA), Vol. 116, No. 4 (Nov.), pp. 1449-1492.

CBS/CPB. 1997. Bevolking en Arbeidsaanbod: Drie Scenario's tot 2020. The Hague, SDU Uitgevers.

Charner, Ivan. 1988. "Employability credentials: A key to successful youth transition to work", in Journal of Career Development (New York, NY), Vol. 15, No. 1, pp. 30-40.

Corvers, Frank. 1997. "The impact of human capital on labour market productivity in manufacturing sectors of the European Union", in Applied Economics (London), Vol. 29, No. 8 (Aug.), pp. 975-987.

de Grip, Andries; Hoevenberg, Jeroen; Willems, Ed. 1997. "Atypical employment in the European Union”, in International Labour Review (Geneva), Vol. 136, No. 1, pp. 4971.

-; van Loo, Jasper. 2002. "The economics of skills obsolescence: A review", in Andries de Grip, Jasper van Loo and Ken Mayhew (eds.): The economics of skills obsolescence: Theoretical innovations and empirical applications. Research in Labor Economics Series, No. 21. Amsterdam, JAI Press, pp. 1-26. 
Down, Simon; Smith, D. 1998: "It pays to be nice people: Investors in people; The search for measurable benefits", in Personnel Review (Bradford), Vol. 27, No. 2, pp. 143-155.

European Commission. 2000. Lisbon European Council, 23 and 24 March 2000: Presidency conclusions. Brussels.

-.1996. Teaching and learning: Towards the learning society. White Paper on Education and Training, COM(95)590. Brussels.

Feintuch, Alfred. 1955. Improving the employability and attitudes of 'difficult to place' persons. Psychological Monographs Series, No. 392. Washington, DC, American Psychological Association.

Forsyth, G. R.; Nininger, J. R. 1966. Expanding employability in Ontario: An assessment of the federal-provincial program for training and upgrading the skills of the unemployed and its implications for governments, business, and labour. Toronto, Ontario Economic Council.

Gaspersz, Jeff; Ott, Marlies. 1996. Management van Employability: Nieuwe Kansen in Arbeidsrelaties. Assen, Van Gorcum.

Gazier, Bernard. 1999. "Employability: An evolutionary notion, an interactive concept", in Bernard Gazier (ed.): Employability: Concepts and policies. Berlin, Institute for Applied Socio-Economics, pp. 37-67.

-.1990. "L'Employabilité: brève radiographie d'un concept en mutation", in Sociologie du Travail (Montrouge), Vol. 32, No. 4, pp. 575-584.

Hall, Douglas T. 1996. The career is dead - Long live the career: A relational approach to careers. San Francisco, CA, Jossey-Bass.

- .1976. Careers in organizations. Glenview, IL, Scott Foresman.

-; Mirvis, P. H. 1996. "The new protean career: psychological success and the path with a heart", in Douglas T. Hall (ed.): The career is dead - Long live the career. San Francisco, CA, Jossey-Bass, pp. 15-45.

Handy, Charles. 1989. The age of unreason. Boston, MA, Harvard Business School Press.

Hashimoto, Masamori. 1981. "Firm-specific human capital as a shared investment", in American Economic Review (Nashville, TN), Vol. 71, No. 3 (June), pp. 475-482.

Heckman, James J. 1999. Policies to foster human capital. NBER Working Paper No. 7288. Cambridge, MA, National Bureau of Economic Research.

Hirsch, Fred. 1977. Social limits to growth. London, Routledge and Regan Paul.

Holtmann, A. G. 1972. "On-the-job training, obsolescence, options, and retraining", in Southern Economic Journal (Chapel Hill, NC), Vol. 38, No. 3 (Jan.), pp. 414-417.

Hoyt, K. B. 1978. "Employability: Are the schools responsible?", in Lewis Solmon (ed.): Reassessing the link between work and education. New Directions for Education and Work Series, No. 1. San Francisco, CA, Jossey-Bass.

Hyatt, Carole. 1996. Lifetime employability: How to become indispensable. New York, NY, Mastermedia Limited.

ILO. 2000. Training for employment: Social inclusion, productivity and youth employment. International Labour Conference, 88th Session, Report V. Geneva.

Levy, J. M.; Jessop, D. J.; Rimmerman, A.; Levy, P. H. 1992. “Attitudes of Fortune 500 corporate executives toward the employability of persons with severe disabilities: A national survey", in Mental Retardation (New York, NY), Vol. 30, No. 2, pp. 67-75.

Lindbeck, Assar; Snower, Dennis. 2000. "Multi-task learning and the reorganization of work, from Tayloristic to holistic organization", in Journal of Labour Economics (Chicago, IL), Vol. 18, No. 3 (July), pp. 353-376.

Mangum, Garth L. 1976. Employability, employment and income: A reassessment of manpower policy. Salt Lake City, UT, Olympus.

Mansfield, Malcom. 2001. "Flying to the moon: Reconsidering the British labour exchange system in the early twentieth century", in Labour History Review (Sheffield), Vol. 66, No. 1 (Spring).

Maroy, Christian; Fusulier, Bernard. 1995. Modernisation des entreprises et formation des salariés. Brussels, BELSPO. 
Neuman, Shoshana; Weiss, Avi. 1995. "On the effects of schooling vintage on experienceearnings profiles: Theory and evidence", in European Economic Review (Amsterdam), Vol. 39, No. 5, pp. 943-955.

Orr, David B. (ed.). 1973. New directions in employability: Reducing barriers to full employment. New York, NY, Praeger Publishers.

Outin, Jean-Luc. 1990. "Trajectoires professionelles et mobilité de la main-d'oeuvre: La construction sociale de l'employabilité", in Sociologie du Travail (Montrouge), Vol. 32. No. 4, pp. 469-489.

Pearson, R. W. 1988. "Creating flexible careers: Some observations on a 'bridge' programme for unemployed professionals", in British Journal of Guidance and Counseling (Abingdon), Vol. 16, No. 3, pp. 250-267.

Porter, Michael E. 1990. The competitive advantage of nations. New York, NY, The Free Press.

-; Stern, Scott. 1999. The new challenge to America's prosperity: Findings from the Innovation Index. Washington, DC, Council of Competitiveness.

Riddell, W. Craig; Sweetman, Arthur. 2000. "Human capital formation in a period of rapid change", in W. Craig Riddell and France St-Hiliaire (eds.): Adapting public policy to a labour market in transition. Montreal, Institute for Research on Public Policy, pp. 85151.

ROA. 1997. De Arbeidsmarkt naar Opleiding en Beroep tot 2002. Report ROA-R-1997/7. Maastricht, Researchcentrum voor Onderwijs en Arbeidsmarkt.

Rosen, Sherwin. 1975. "Measuring the obsolescence of knowledge", in F. Thomas Juster (ed.): Education, income and human behavior. New York, NY, McGraw Hill, pp. 199232.

Smith, David C. 1976. The dual labour market theory: A Canadian perspective. Kingston, Industrial Relations Centre, Queen's University.

Soloff, A.; Bolton, B. F. 1969. "The validity of the CJVS-scale of employability for older clients in a vocational adjustment workshop", in Educational and Psychological Measurement (Thousand Oaks, CA), Vol. 29, pp. 993-998.

Sterns, H. L.; Dorsett, J. G. 1994. "Career development: A life span issue”, in Experimental Aging Research (Bristol, PA), Vol. 20, No. 4 (Special Issue on "Cognition, work, technology and environmental design for the elderly"), pp. 257-264.

Stevens, M. 1994. "A theoretical model of on-the-job training with imperfect competition", in Oxford Economic Papers (Oxford), Vol. 46, pp. 537-562.

Thijssen, J. 1998. Employability: Conceptuele Varianten en Componenten. Utrecht, FSW, University of Utrecht.

-.1997. "Employability en Employment: Terminologie, Modelvorming en Opleidingspraktijk", in Opleiding en Ontwikkeling (The Hague), Vol. 10, No. 10, pp. 9-14.

Thurow, Lester C. 1975. Generating inequality. New York, NY, MacMillan.

Tseng, M. S. 1972. "Self-perception and employability: A vocational rehabilitation problem", in Journal of Counseling Psychology (Washington, DC), Vol. 19, No. 4, pp. 314-317.

Weisenstein, G. R. 1979. "Barriers to employability of the handicapped: Some educational implications", in Journal of Research and Development in Education (Athens, GA), Vol. 12, No. 4, pp. 57-70.

Wood, Adrian. 1994. North-South trade, employment and inequality: Changing fortunes in a skill driven world. Oxford, Clarendon Press. 